\title{
PERBEDAAN TINGKAT KESEHATAN BANK UMUM KONVENSIONAL DAN BANK UMUM SYARIAH YANG TERDAFTAR DI BURSA EFEK INDONESIA (BEI)
}

\author{
Ervita Safitri, Fildhzah Rani, Darma Yanti ${ }^{凶}$
}

Jurusan Manajemen, Universitas Muhammadiyah Palembang

Jurusan Akuntansi, Universitas Muhammadiyah Palembang

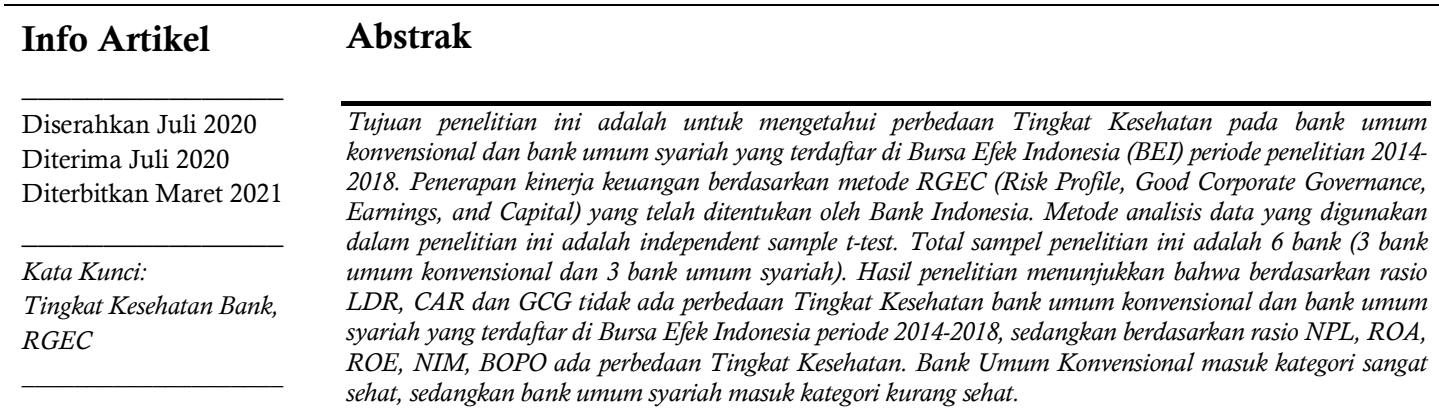

(C) 2021 Indonesia

Alamat Korespondensi:

Fakultas Ekonomi Dan Bisnis

ISSN 2548-9909

Universitas Muhammadiyah Palembang

E-mail: darmayanti@um-palembang.ac.id 


\section{Pendahuluan}

Indonesia memiliki dua jenis bank yang dibedakan berdasarkan jenis fungsinya, yaitu Bank Umum Konvensional dan Bank Umum Syariah. Bank konvensional lebih dahulu beroperasi dibandingkan bank syariah, hal ini disebabkan adanya sistem perbankan yang memberlakukan UU Perbankan No.7 tahun 1992 tentang dual system bank yang sekarang diamandemen dengan UU No.10 Tahun 1998.

Sistem perbankan

ini memperbolehkan bank bank konvensional beroperasi berdasarkan prinsip syariah dengan membuka Unit Usaha Syariah (UUS) sehingga mempercepat pertumbuhan perbankan syariah (Masterpaln Arsitektur Keuangan Syariah Indonesia, 2015). Salah satu fenomena persaingan di dalam industri perbankan dapat dilihat dari semakin berkembangnya bank syariah dan masih kuatnya bank konvensional. Terlebih lagi bank syariah yang harus bersaing dengan bank konvensional yang dominan dan telah berkembang pesat lebih dulu di Indonesia.

Bank Umum Konvensional maupun dengan syariah, membuat keduanya dituntut untuk memiliki kinerja yang bagus agar dapat bersaing dalam memperebutkan pasar perbankan nasional di Indonesia, hal ini membuat Bank Indonesia selaku Bank Central Indonesia yang bertugas untuk mengatur dan mengawasi bank makin memperketat dalam pengaturan dan pengawasan perbankan nasional.

Bank Indonesia tidak ingin mengulangi peristiwa di awal krisis ekonomi pada tanggal 1 November tahun 1997 dimana sebanyak 16 bank dilikuidasi karena kinerjanya tidak sehat, yang pada akhirnya merugikan masyarakat dan telah mengguncang kepercayaan masyarakat. Kesehatan suatu bank dapat dilihat dari kinerja keuangan bank yang bersangkutan dan itu tercermin dari informasi yang diperoleh pada laporan keuangannya. Laporan keuangan adalah laporan yang menunjukkan kondisi keuangan perusahaan pada saat ini atau dalam periode tertentu (Kasmir, 2015:7). Berdasarkan laporan keuangan tersebut terlihat pos-pos mana yang mengalami peningkatan atau penurunan yang juga akan menentukan langkah apa yang dilakukan bank untuk sekarang maupun ke depannya.

Peristiwa terbesar kembali terjadi pada tahun 2008 yang mana mengakibatkan suatu bank harus dilikuidasi dan hingga saat ini masih diperbincangkan yaitu kasus Bank Century. Kasus Bank Century berawal dari jatuh temponya surat berharga milik Bank Century senilai US\$ 56 juta yang pada akhirnya mengalami gagal bayar menyebabkan Bank century mengalami kesulitan likuiditas, kemudian gagal kliring karena gagal menyediakan dana (prefund) dan mengakibatkan terjadi penarikan dana secara besar-besaran (rush).

Kasus Bank Century membuat Bank Indonesia memperbaiki sistem penilaian kesehatan bank yang telah banyak mengalami perubahan. Sejak pertama kali diberlakukan pada tahun 1999 yaitu metode CAMEL, kemudian menjadi CAMELS dan sekarang berdasarkan Surat Edaran Bank Indonesia No.13/24/DPNP Tahun 2011 Bank Indonesia memberlakukan secara efektif metode RGEC sebagai penilaian tingkat kesehatan bank yang terdiri dari risk profile (profil risiko), good corporate governance, earning (rentabilitas), dan capital (permodalan). Bank Indonesia menginginkan bank mampu mengidentifikasi permasalahan secara lebih dini, melakukan tindak lanjut perbaikan yang sesuai dan lebih cepat, serta menerapkan Good Corporate Governance (GCG) dan manajemen risiko yang lebih baik. Dengan demikian masalah seperti Bank Century tidak terulang kembali serta perbaikan sistem penilaian ini diharapkan dapat menumbuhkan kepercayaan masyarakat kembali.

Bank merupakan lembaga keuangan sebagai tempat perusahaan menyimpan uang atau menitipkan uangnya dalam bentuk simpanan. Jenis simpanan yang ada di bank seperti rekening giro, dan rekening tabungan (Kasmir 2015: 360). Menurut Booklet Perbankan Indonesia (2014), bank konvensional adalah bank yang kegiatan 
usahanya dijalankan secara konvensional dan jenisnya terdiri dari Bank Umum Konvensional (BUK) dan Bank Perkreditan Rakyat (BPR), sedangkan bank syariah dan jenisnya terdiri dari Bank Umum Syariah (BUS) dan Bank Pembiayaan Rakyat Syariah (BPRS).

\section{Tingkat Kesehatan Bank}

Menurut Surat Edaran Bank Indonesia No.6/23/DPNP tahun 2004, Tingkat Kesehatan Bank merupakan hasil penilaian kualitatif atas berbagai aspek yang berpengaruh terhadap kondisi atau kinerja suatu Bank melalui penilaian faktor permodalan, kualitas aset, manajemen, rentabilitas, likuiditas dan sensitivitas terhadap risiko pasar.

Tabel 1. Bobot Penetapan Peringkat Komposit Kesehatan Bank dengan Metode RGEC

\begin{tabular}{|c|c|c|}
\hline Bobot \% & Peringkat & Keterangan \\
\hline $86-100$ & PK 1 & Sangat Sehat \\
\hline $71-85$ & PK 2 & Sehat \\
\hline $61-70$ & PK 3 & Cukup Sehat \\
\hline $41-60$ & PK 4 & Kurang Sehat \\
\hline$<40$ & PK 5 & Tidak Sehat \\
\hline
\end{tabular}

Sumber : Refmasari dan Setiawan (2014)

Nilai Komposit untuk rasio keuangan masing-masing komponen yang menenpati peringkat komposit akan bernilai sebagai berikut:

1) Peringkat $1=$ setiap kali ceklist dikalikan 5

2) Peringkat $2=$ setiap kali ceklist dikalikan 4

3) Peringkat $3=$ setiap kali ceklist dikalikan 3

4) Peringkat $4=$ setiap kali ceklist dikalikan 2

5) Peringkat 5 = setiap kali ceklist dikalikan 1 Sumber: Refmasari dan Setiawan (2014)

\section{Risk Profile}

Risiko Profile diproksikan dengan rasio NPL (non-Performing Loan) dan LDR (Loan to Deposit Ratio) seperti yang termuat dalam laporan keuangan publikasi. Berdasarkan PBI No17/11/PBI/2015 tentang Perubahan atas Peraturan Bank Indonesia No 15/15/PBI 2013 menentukan nilai rasio NPL total kredit secara bruto (Gross NPL) bank tidak boleh melebihi $5 \%$. Sehingga semakin tinggi rasio ini maka akan semakin buruk kualitas kredit bank yang mengakibatkan jumlah kredit bermasalah semakin besar maka kemungkinan suatu bank dalam kondisi bermasalah semakin besar pula. Loan to deposit ratio (LDR) merupakan rasio yang digunakan untuk mengukur komposisi jumlah kredit yang diberikan dibandingkan dengan jumlah dana masyarakat dan modal sendiri yang digunakan. semakin tinggi rasio LDR kemungkinan jumlah kredit yang akan diberikan menjadi semakin meningkat.

\section{Good Corporate Governance (GCG)}

Penilaian faktor GCG merupakan penilaian terhadap kualitas manajemen Bank atas pelaksanaan prinsip-prinsip GCG. Good Coparate Governance (GCG) berarti suatu proses dan struktur yang digunakan untuk mengarahkan dan mengelola bisnis dan akuntabilitas perusahaan dengan tujuan utama mempertinggi nilai saham dalam jangka panjang dengan tetap memerhatikan kepentingan Stakeholders lain. Penilaian Good Coparate Governance (GCG) ini wajib dilakukan oleh masing-masing bank (Self Asessment) melalui laporan Self Asessment pelaksanaan Good Coparate Governance sesuai SE BI No.13/24/DPNP tanggal 25 Oktober 2011.

\section{Earnings}

Earnings adalah salah satu penilaian kesehatan bank dari sisi rentabilitas. Indikator penilaian rentabilitas adalah ROA (Return On Assets), ROE (Return On Equity), NIM (Net Interest Margin), dan BOPO (Beban Operasional Terhadap Pendapatan Operasional). Karakteristik bank dari sisi rentabilitas adalah kinerja bank dalam menghasilkan laba, kestabilan komponenkomponen yang mendukung core earning, dan kemampuan laba dalam meningkatkan permodalan dan prospek laba di masa depan.

Return on Assets (ROA) digunakan untuk mengukur kemampuan bank dalam memperoleh keuntungan secara keseluruhan. Standar ketentuan BI adalah sebesar $>1,5 \%$. Semakin besar ROA suatu bank, semakin besar pula tingkat keuntungan yang dicapai bank 
tersebut dan semakin baik pula posisi bank tersebut dari segi penggunaan aset.

Standar ketentuan PBI No.15/7/PBI Tahun 2013 adalah 8,32\%. Semakin tinggi persentase ROE yang diperoleh maka semakin besar kenaikan laba bersih yang diperoleh oleh bank, begitupun sebaliknya semakin rendah persentase ROE maka semakin kecil laba bersih yang diterima oleh bank.

Rasio biaya operasional digunakan untuk mengukur tingkat efisiensi dan kemampuan bank dalam melakukan kegiatan operasi. Surat edaran BI No.6/9/PBI/2004 ketentuan standar BOPO yaitu sebesar $92 \%$. Semakin tinggi angka BOPO maka akan menunjukkan kurangnya kemampuan bank dalam menekan biaya operasionalnya sehingga dapat menimbulkan ketidakefisienan.

Ketidak efisienan ini menimbulkan alokasi biaya yang lebih tinggi sehingga dapat menurunkan pendapatan bank. Semakin kecil rasio ini menunjukkan semakin efisien biaya operasional yang dikeluarkan bank sehingga kemungkinan bank akan menghadapi kondisi bermasalah akan semakin kecil. Semakin besar rasio ini maka meningkatkan pendapatan bunga. Semakin besar rasio ini maka meningkatkan pendapatan bunga atas aktiva produktif yang dikelola bank sehingga kemungkinan suatu bank dalam mengalami kesulitan keuangan semakin kecil. Standar ketentuan rasio NIM sesuai PBI yaitu $6 \%$.

\section{Capital}

CAR (Capital Adequacy Ratio) adalah rasio kinerja bank untuk mengukur kecukupan modal yang dimiliki bank untuk menunjang aktiva yang mengandung atau menghasilkan risiko. Standar rasio CAR ketentuan PBI No.15/2/PBI Tahun 2013 yaitu sebesar 8\%.

\section{Metode}

\subsection{Populasi dan Sampel}

Lokasi penelitian ini adalah Bursa Efek Indonesia melalui Galeri Investasi Universitas Muhammadiyah Palembang yang berupa data sekunder yaitu laporan keuangan dari situs resmi http://www.idx.co.id. Variabel penelitian ini adalah Tingkat Kesehatan Bank dengan Metode RGEC. Populasi penelitian ini adalah seluruh sektor bank konvensional yang terdaftar di BEI periode 2014-2018, dengan metode purposive sampling dan melalui beberapa kriteria penentuan maka diperoleh sebanyak 3 Bank Umum Konvensional dan 3 Bank Umum Syariah sebagai sampel penelitian ini. Teknik analisis data yang digunakan adalah analisis Independent Sample t-test digunakan untuk menjelaskan perbedaan tingkat kesehatan Bank Umum Konvensional dan Bank Umum Syariah yang terdaftar di BEI periode 2014-2018.

\section{Hasil dan Pembahasan}

\subsection{Anilisis Kinerja Keuangan}

Analisis penelititan ini untuk menilai kinerja perusahaan sampel bank berdasarkan metode RGEC yang terdiri dari hasil risk profile, good corporate governance, earning dan capital. Adapun analisis kinerja keuangan bank umum konvensional dan bank umum syariah.

Risk profile yang di ukur dengan rasio NPL menunjukkan bahwa nilai rata-rata kinerja bank konvensional 2,68\% dan bank syariah 4,86\%. Hal ini menunjukkan bahwa kinerja bank konvensioanl memiliki kinerja yang baik dalam menjaga dan mengembalikan aset yang ditanamkan oleh pihak ke tiga, sedangkan bank syariah termasuk kedalam kinerja yang cukup sehat atau memiliki kinerja yang kurang baik dalam mengelola kreditnya dan kurang mampu mengembalikan aset yang ditanamkan oleh pihak ketiga.

Kinerja keuangan bank dengan dengan rasio LDR memiliki rata-rata $81,80 \%$ untuk bank konvensional dan rata-rata $86,21 \%$ untuk bank syariah. Hal ini menunjukkan bahwa kinerja bank konvensional sangat baik dalam membayar kembali kewajiban kepada para nasabah yang telah menanamkan dananya dengan kredit-kredit yang telah diberikan. Sedangkan bank syariah memiliki kinerja yang cukup baik dalam membayarkan kembali kewajiban kepada para nasabah.

Pengukuran kinerja bank dengan good corporate governance keduanya masuk dalam kategori baik dengan rasio GCG bank konvensional $1,85 \%$ dan $1,68 \%$ bank syariah 
artinya kedua jenis bank melakukan penerapan GCG pada aspek governance structure, governance process, dan governance outcome yang secara umum Baik. Hal ini tercermin dari pemenuhan memadai atas atas perinsip- prinsip good corporate governance. Apabila terdapat kelemahan dalam penerapan prinsip-prinsip GCG, maka secara umum kelemahan tersebut kurang signifikan dan dapat diselesaikan dengan tindakan normal oleh manajemen

Rasio ROA yang diterapkan dengan hasil rata-rata untuk bank konvensional sebesar 2,49\% tergolong sangat sehat menunjukkan bahwa tingkat pengembalian atas aset ataupun atas modal yang dimiliki bank konvensional untuk memperoleh keuntungan lebih baik dari pada bank syariah dengan rasio ROA sebesar 0,25\% kategori kurang sehat. Analisis return on equity (ROE) menunjukkan 16,04\% untuk bank konvensioanal berarti sehat dan 2,05\% bank syariah yang berarti kurang sehat yang menunjukkan bahwa bank syariah kurang mampu dalam menghasilkan laba dimasa yang akan datang. Kinerja keuangan dengan rasio BOPO 78,39\% sangat sehat untuk bank konvensioanal artinya kemampuan manajemen bank konvensional dalam mengendalikan biaya operasional yang dikeluarkan terhadap pendapatan operasional sangat efisien dari pada bank syariah dengan rasio 100,07\% tidak sehat sehingga kemungkinan bank konvensional dalam kondisi bermasalah semakin kecil.

Capital merupakan rasio CAR dari bank konvensional sebeasar 19,91\% besarti sangat sehat begitu juga dengan bank syariah sebesar 18,13\%. Artinya kedua bank tersebut memiliki tingkat kecukupan modal yang baik atas pemenuhan kewajiban yang dimilikinya, baik dalam mendanai kegiatan operasionalnya ataupun untuk menghadapi risiko yang mungkin akan terjadi.

\subsection{Analisis Tingkat Kesehatan Bank}

Analisis keinerja bank dilakukan untuk melihat tingkat kesehatan bank yang secara menyeluruh diukur dengan metode RGEC. Bank Umum Konvensional masuk Peringkat Komposit 1 (PK-1) sebesar 90,00\% yaitu mencerminkan kondisi bank yang secara umum sangat sehat sehingga dinilai sangat mampu menghadapi pengaruh negatif yang signifikan dari perubahan kondisi bisnis dan faktor eksternal lainnya.

Tabel. 2 Tingkat Kesehatan Bank Umum Konvensional

\begin{tabular}{|c|c|c|c|c|c|c|c|c|c|c|}
\hline \multirow{2}{*}{$\begin{array}{l}\text { Komponen } \\
\text { faktor }\end{array}$} & \multirow{2}{*}{ Rasio } & \multirow{2}{*}{ Nilai } & \multicolumn{5}{|c|}{ Kriteria } & \multirow{2}{*}{ Kriteria } & \multirow{2}{*}{ Ket } & \multirow{2}{*}{ PK } \\
\hline & & & 1 & 2 & 3 & 4 & 5 & & & \\
\hline Risk & NPL & $2,68 \%$ & & $\sqrt{ }$ & & & & Sehat & \multirow{2}{*}{ sehat } & \multirow{9}{*}{$\begin{array}{l}\text { Sangat } \\
\text { sehat }\end{array}$} \\
\hline Profile & LDR & $81,80 \%$ & & $\sqrt{ }$ & & & & Sehat & & \\
\hline GCG & GCG & 1,85 & & $\sqrt{ }$ & & & & Sehat & sehat & \\
\hline \multirow{4}{*}{ Earnings } & ROA & $2,49 \%$ & $\sqrt{ }$ & & & & & Sangat sehat & \multirow{4}{*}{$\begin{array}{c}\text { Sangat } \\
\text { sehat }\end{array}$} & \\
\hline & $\mathrm{ROE}$ & $16,04 \%$ & & $\sqrt{ }$ & & & & Sehat & & \\
\hline & NIM & $5,26 \%$ & $\sqrt{ }$ & & & & & Sangat sehat & & \\
\hline & $\mathrm{BOPO}$ & $78,39 \%$ & $\sqrt{ }$ & & & & & Sangat sehat & & \\
\hline Capital & CAR & $19,91 \%$ & $\sqrt{ }$ & & & & & Sangat sehat & $\begin{array}{c}\text { Sangat } \\
\text { sehat }\end{array}$ & \\
\hline \multicolumn{2}{|c|}{ Nilai Komposit } & 40 & 20 & 16 & - & - & - & \multicolumn{2}{|c|}{$(36 / 40) * 100=90,00 \%$} & \\
\hline
\end{tabular}

Sumber: Data diolah penulis, 2020

Bank syariah masuk kategori kurang sehat dengan presentase nilai komposit sebesar 55,00\% hal ini menunjukkan bahwa bank syariah masuk peringkat komposit $4 \quad(\mathrm{PK}-4)$ yaitu mencerminkan kondisi bank yang secara umum

kurang sehat sehingga dinilai kurang mampu menghadapi pengaruh negatif yang signifikan dari perubahan kondisi bisnis dan faktor eksternal lainnya 
Tabel.3 Tingkat Kesehatan bank Umum Syariah

\begin{tabular}{|c|c|c|c|c|c|c|c|c|c|c|}
\hline \multirow{2}{*}{$\begin{array}{l}\text { Kompone } \\
\text { n faktor }\end{array}$} & \multirow{2}{*}{ Rasio } & \multirow{2}{*}{ Nilai } & \multicolumn{5}{|c|}{ Kriteria } & \multirow{2}{*}{ Kriteria } & \multirow{2}{*}{ Ket } & \multirow{2}{*}{ PK } \\
\hline & & & 1 & 2 & 3 & 4 & 5 & & & \\
\hline \multirow[t]{2}{*}{$\begin{array}{c}\text { Risk } \\
\text { Profile }\end{array}$} & $\mathrm{NPF}$ & $4.86 \%$ & & & $\sqrt{ }$ & & & $\begin{array}{l}\text { Cukup } \\
\text { Sehat }\end{array}$ & \multirow[t]{2}{*}{ sehat } & \multirow{9}{*}{$\begin{array}{l}\text { Kurang } \\
\text { sehat }\end{array}$} \\
\hline & $\overline{\text { FDR }}$ & $86,21 \%$ & & & $\sqrt{ }$ & & & $\begin{array}{l}\text { Cukup } \\
\text { Sehat }\end{array}$ & & \\
\hline GCG & GCG & 1,68 & & $\sqrt{ }$ & & & & Sehat & sehat & \\
\hline \multirow{4}{*}{ Earnings } & $\underline{\mathrm{ROA}}$ & $0.25 \%$ & & & & $\sqrt{ }$ & & Tidak sehat & \multirow{4}{*}{$\begin{array}{l}\text { Kurang } \\
\text { Sehat }\end{array}$} & \\
\hline & $\overline{\mathrm{ROE}}$ & $2,05 \%$ & & $\sqrt{ }$ & & & & $\begin{array}{c}\text { Kurang } \\
\text { Sehat }\end{array}$ & & \\
\hline & NIM & $1,65 \%$ & & & $\sqrt{ }$ & & & $\begin{array}{l}\text { Cukup } \\
\text { sehat }\end{array}$ & & \\
\hline & $\mathrm{BOPO}$ & $100.07 \%$ & & & & & $\sqrt{ }$ & Tidak sehat & & \\
\hline Capital & CAR & $18.13 \%$ & $\sqrt{ }$ & & & & & $\begin{array}{c}\text { Sangat } \\
\text { sehat }\end{array}$ & $\begin{array}{l}\text { Sangat } \\
\text { sehat }\end{array}$ & \\
\hline $\begin{array}{l}\text { Nilai } \\
\text { Komposit }\end{array}$ & & 40 & 5 & 4 & 9 & 2 & 2 & $(22 / 40) * 100$ & $=55,00 \%$ & \\
\hline
\end{tabular}

Sumber: Data diolah penulis, 2020

\subsection{Perbedaan Kinerja Keuangan Bank}

Penelitian ini menggunakan pengujian hipotesis Independent Sample T-test untuk melihat adakah perbedaan kinerja keuangan Bank Umum Konvensional dan Bank Umum Syariah

\section{Aspek risk profile}

Tabel 4. Hasil Uji Independent sample T-test NPL

\begin{tabular}{|c|c|c|c|c|c|c|c|c|}
\hline & & \multicolumn{2}{|c|}{$\begin{array}{c}\text { Levene's Test } \\
\text { for Equality of } \\
\text { Variances }\end{array}$} & \multicolumn{4}{|c|}{ t-test for Equality of Means } & \multirow[b]{2}{*}{$\begin{array}{l}\text { Std. Error } \\
\text { Difference }\end{array}$} \\
\hline & & $\mathrm{F}$ & Sig. & $\mathrm{t}$ & df & $\begin{array}{l}\text { Sig. }(2- \\
\text { tailed) }\end{array}$ & $\begin{array}{c}\text { Mean } \\
\text { Difference }\end{array}$ & \\
\hline \multirow[t]{2}{*}{ NPL } & $\begin{array}{l}\text { Equal variances } \\
\text { assumed }\end{array}$ & 8,480 &, 007 & $-3,592$ & 28 & 001 & $-2,18267$ & ,60773 \\
\hline & $\begin{array}{l}\text { Equal variances } \\
\text { not assumed }\end{array}$ & & & $-3,592$ & 18,042 & ,002 & $-2,18267$ & ,60773 \\
\hline
\end{tabular}

Sumber: Hasil output SPSS versi 25, 2020

F hitung untuk rasio NPL adalah pada Levene's Test sebesar 8,480 dengan probabilitas sebesar 0,007 karena $<0,05$ maka dapat disimpulkan bahwa memiliki variance yang tidak sama. Dengan demikian analisis uji beda ttest menggunakan asumsi equal variances not assumed. Jika dilihat dari T-Test pada equal variances not assumed sebesar -3,592 dengan probabilitas signifikansi 0,002 (2-tailed). Nilai ttabel dengan taraf nyata $(\alpha)=5 \%$ dan $\mathrm{df}(\mathrm{n}-2)=$ $30-2=28$, adalah sebesar 2,048. Hal ini berarti $\mathrm{t}$ hitung $-3,592>\mathrm{t}$ tabel $-2,048$, atau nilai signifikan t hitung $0,002<0,05$ maka Ho ditolak dan Ha diterima. Artinya berdasarkan rasio NPL/NPF ada perbedaan tingkat kesehatan bank umum konvensional dan bank umum syariah. Perbedaan tingkat kesehatan bank umum konvensional dan bank umum syariah dikategorikan sehat untuk bank umum konvensioanl dengan masuk peringkat komposit 1(PK-1) secara umum sangat sehat, mampu menghadapi pengaruh negatif yang signifikan dari perubahan kondisi bisnis serta faktor eksternal lainnya dari aspek earings dan aspek capital saja yang masuk kondisi rentabilitas bank sangat memadai, laba melebihi target dan 
mendukung pertumbuhan permodalan bank serta memiliki kualitas dan kecukupan permodalan yang sangat memadai dan kuat.

Bank umum syariah masuk kategori kurang sehat dengan masuk peringkat komposit 4 (PK-4) secara umum kurang sehat. Aspek risk profile yang terdiri dari resiko kredit harus diperhatikan karena berada pada kategori cukup sehat yang kondisi kualitas manajemen resiko cukup memadai meskipun terdapat beberapa kelemahan yang membutuhkan perhatian dari manajemen. Aspek earnings juga harus diperhatikan, karena berada di kategori kurang sehat karena rasio ROA dan ROE yang berada dibawah standar ketentuan peraturan bank indonesia yaitu sebesar $1,5 \%$ dan $8,32 \%$ sehingga rentabilitas menunjukan bahwa rentabilitas kurang memadai, laba kurang memenuhi target dan tidak dapat diandalkan serta memerlukan peningkatan kinerja laba segera untuk memastikan kelangsungan usaha bank. Aspek capital saja yang masuk dalam kriteria sangat sehat, hal ini menunjukkan bahwa memiliki kualitas dan kecukupan permodalan yang sangat memadai dan kuat.

Tabel 5. Hasil Uji Independent Sample T-Test LDR

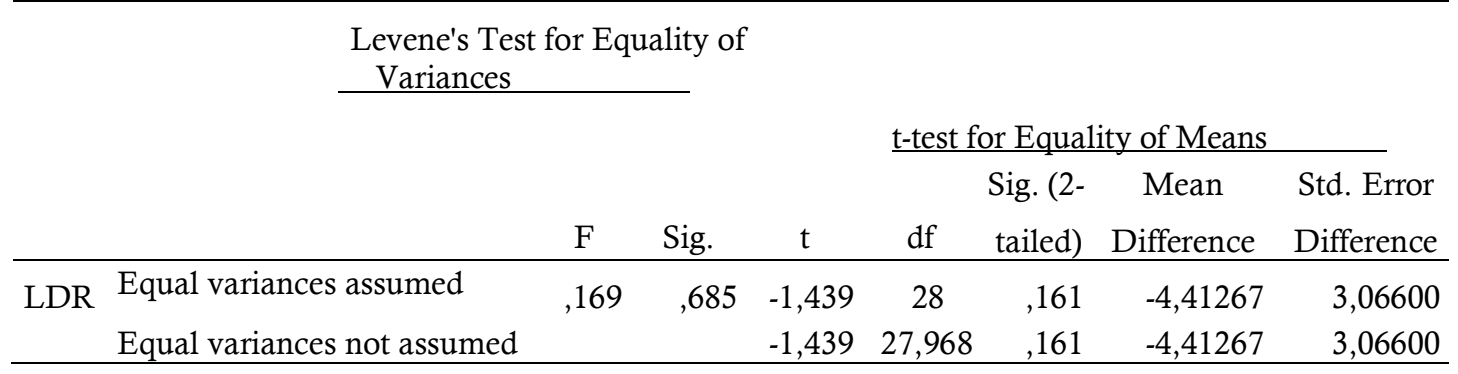

Sumber: Hasil output SPSS versi 25, 2020.

$\mathrm{F}$ hitung untuk rasio LDR adalah pada Levene's Test sebesar 0,169 dengan probabilitas sebesar 0,685 karena $>0,05$ maka dapat disimpulkan bahwa memiliki variance yang sama. Dengan demikian analisis uji beda t-test menggunakan asumsi equal variances assumed. Jika dilihat dari T-Test pada equal variances assumed sebesar -1,439 dengan probabilitas signifikansi 0,161 (2-tailed). Nilai t-tabel dengan taraf nyata $(\alpha)=5 \%$ dan df $(n-2)=30-2=28$, adalah sebesar 2,048. Hal ini berarti t hitung $1,439<\mathrm{t}$ tabel $-2,048$, atau nilai signifikan thitung 0,161 > 0,05 maka Ho diterima dan Ha ditolak. Artinya berdasarkan rasio Loan to deposit ratio (LDR) tidak ada perbedaan tingkat kesehatan bank umum konvensional dan bank umum syariah.

Tabel 6. Hasil uji independent sample T-test GCG

\begin{tabular}{|c|c|c|c|c|c|c|c|}
\hline & \multicolumn{2}{|c|}{$\begin{array}{c}\text { Levene's Test } \\
\text { for Equality of } \\
\text { Variances } \\
\end{array}$} & \multicolumn{5}{|c|}{ t-test for Equality of Means } \\
\hline & $\mathrm{F}$ & Sig. & $\underline{\mathrm{t}}$ & $\underline{\mathrm{df}}$ & $\begin{array}{l}\text { Sig. }(2- \\
\text { tailed) } \\
\end{array}$ & $\begin{array}{c}\text { Mean } \\
\text { Difference }\end{array}$ & $\begin{array}{l}\text { Std. Error } \\
\text { Difference }\end{array}$ \\
\hline $\begin{array}{l}\text { Equal variances } \\
\text { assumed }\end{array}$ & ,091 &, 765 & 1,514 & 28 &, 141 & ,16733 & ,11051 \\
\hline $\begin{array}{l}\text { Equal variances } \\
\text { not assumed }\end{array}$ & & & 1,514 & 27,827 &, 141 & ,16733 & ,11051 \\
\hline
\end{tabular}


sama. Dengan demikian analisis uji beda t-test menggunakan asumsi equal variances assumed. Jika dilihat dari T-Test pada equal variances assumed sebesar 1,514 dengan probabilitas signifikansi 0,141 (2-tailed). Nilai t-tabel dengan taraf nyata $(\alpha)=5 \%$ dan df $(n-2)=30-2=28$ adalah sebesar 2,048. Hal ini berarti t hitung
1,514 < t tabel 2,048, atau nilai signifikan $\mathrm{t}$ hitung 0,141 >0,05 maka Ho diterima dan $\mathrm{Ha}$ ditolak. Artinya dari aspek good corparate governance (GCG) tidak ada perbedaan tingkat kesehatan bank umum konvensional dan bank umum syariah yang terdaftar di bursa efek indonesia periode 2014-2018

\section{Aspek Eaning}

Tabel 7. Hasil Uji Independent Sample T-test ROA

\begin{tabular}{|c|c|c|c|c|c|c|c|c|c|}
\hline & \multicolumn{4}{|c|}{$\begin{array}{l}\text { Levene's Test for Equality } \\
\text { of } \\
\text { Variances }\end{array}$} & \multicolumn{4}{|c|}{$\underline{\text { t-test for Equality of Means }}$} & \multirow[b]{2}{*}{$\begin{array}{l}\text { Std. Error } \\
\text { Difference }\end{array}$} \\
\hline & & & $\mathrm{F}$ & Sig. & $\underline{\mathrm{t}}$ & $\underline{\mathrm{df}}$ & $\begin{array}{l}\text { Sig. }(2- \\
\text { tailed) }\end{array}$ & $\begin{array}{c}\text { Mean } \\
\text { Difference }\end{array}$ & \\
\hline ROA & Equal variances & $\underline{\text { assumed }}$ & ,961 & ,335 & 4,305 & 28 & ,000 & 2,23333 &, 51879 \\
\hline & $\begin{array}{l}\text { Equal variances } \\
\text { assumed }\end{array}$ & not & & & 4,305 & 27,515 &, 000 & 2,23333 & ,51879 \\
\hline
\end{tabular}

Sumber : Hasil ouput SPSS versi 25, 2020

$\mathrm{F}$ hitung untuk rasio ROA adalah pada Levene's Test sebesar 0,961 dengan probabilitas sebesar 0,335 karena $>0,05$ maka dapat disimpulkan bahwa memiliki variance yang sama. Dengan demikian analisis uji beda t-test menggunakan asumsi equal variances assumed. Jika dilihat dari T-Test pada equal variances assumed sebesar 4,305 dengan probabilitas signifikansi 0,000 (2-tailed). Nilai t-tabel dengan taraf nyata $(\alpha)=5 \%$ dan df $(n-2)=30-2=28$ adalah sebesar 2,048. Hal ini berarti t hitung 4,305 > t tabel 2,048, atau nilai signifikan $\mathrm{t}$ hitung 0,000 $<0,05$ maka Ho ditolak dan $\mathrm{Ha}$ diterima. Artinya berdasarkan rasio ROA ada perbedaan tingkat kesehatan bank umum konvensional dan bank umum syariah.
$\mathrm{F}$ hitung untuk rasio ROE adalah pada Levene's Test sebesar 0,085 dengan probabilitas sebesar 0,773 karena $>0,05$ maka dapat disimpulkan bahwa memiliki variance yang sama. Dengan demikian analisis uji beda t-test menggunakan asumsi equal variances assumed. Jika dilihat dari T-Test pada equal variances assumed sebesar 3,937 dengan probabilitas signifikansi 0,000 (2-tailed). Nilai t-tabel dengan taraf nyata $(\alpha)=5 \%$ dan $\mathrm{df}(\mathrm{n}-2)=30-2=28$, adalah sebesar 2,048. Hal ini berarti t hitung 3,397 > t tabel 2,048, atau nilai signifikan thitung $0,000<0,05$ maka Ho ditolak dan Ha diterima. Artinya berdasarkan rasio Return On Equity (ROE) ada perbedaan tingkat kesehatan bank umum konvensional dan bank umum syariah. 
Tabel 8. Hasil uji independent sample T-tes ROE

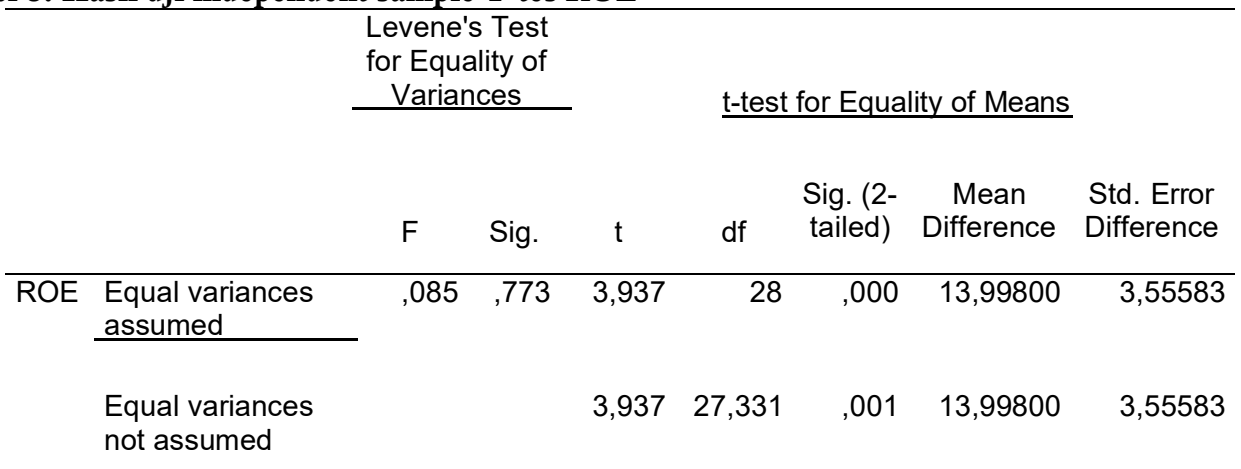

Sumber : Hasil ouput SPSS versi 25, 2020

$\mathrm{F}$ hitung untuk rasio NIM adalah pada

Levene's Test sebesar 1,140 dengan probabilitas sebesar 0,295 karena $>0,05$ maka dapat disimpulkan memiliki variance yang sama. Dengan demikian analisis uji beda t-test menggunakan asumsi equal variances assumed. Jika dilihat dari T-Test pada equal variances assumed sebesar 3,146 dengan probabilitas signifikansi 0,004 (2-tailed). Nilai t-tabel dengan taraf nyata $(\alpha)=5 \%$ dan df $(n-2)=30-2=28$, adalah sebesar 2,048. Hal ini berarti t hitung $3,146>\mathrm{t}$ tabel 2,048, atau nilai signifikan thitung $0,004<0,05$ maka Ho ditolak dan Ha diterima. Artinya berdasarkan rasio Net Interest Margin (NIM) ada perbedaan tingkat kesehatan bank umum konvensional dan bank umum syariah.

Tabel 9. Hasil uji independent sample T-tes NIM

Levene's Test for

Equality of

Variances t-test for Equality of Means

\begin{tabular}{|c|c|c|c|c|c|c|c|c|}
\hline & & $\mathrm{F}$ & Sig. & $\mathrm{t}$ & Df & $\begin{array}{l}\text { Sig. }(2- \\
\text { tailed) }\end{array}$ & $\begin{array}{c}\text { Mean } \\
\text { Difference }\end{array}$ & $\begin{array}{l}\text { Std. Error } \\
\text { Difference }\end{array}$ \\
\hline NIM & $\begin{array}{l}\text { Equal variances } \\
\text { assumed }\end{array}$ & 1,140 & ,295 & 3,146 & 28 & ,004 & 3,61133 & 1,14773 \\
\hline & $\begin{array}{l}\text { Equal variances } \\
\text { not assumed }\end{array}$ & & & 3,146 & 25,851 & ,004 & 3,61133 & 1,14773 \\
\hline
\end{tabular}

Sumber : Hasil ouput SPSS versi 25, 2020

$\mathrm{F}$ hitung untuk rasio BOPO adalah pada

Levene's Test sebesar 0,151 dengan probabilitas sebesar 0,700 karena $>0,05$ maka dapat dengan probabilitas signifikansi 0,001 (2-tailed). Nilai t-tabel dengan taraf nyata $(\alpha)=5 \%$ dan df $(n 2)=30-2=28$, adalah sebesar 2,048 . Hal ini disimpulkan bahwa $\mathrm{H} 0$ tidak dapat ditolak atau memiliki variance yang sama. Dengan demikian analisis uji beda t-test menggunakan asumsi equal variances assumed. Jika dilihat dari TTest pada equal variances assumed sebesar $-3,927$ berarti t hitung $-3,927>\mathrm{t}$ tabel $-2,048$, atau nilai signifikan thitung $0,001<0,05$ maka Ho ditolak dan Ha diterima. Artinya berdasarkan rasio BOPO ada perbedaan tingkat kesehatan bank umum konvensional dan bank umum syariah. 
Tabel 10. Hasil uji independent sample T-tes BOPO

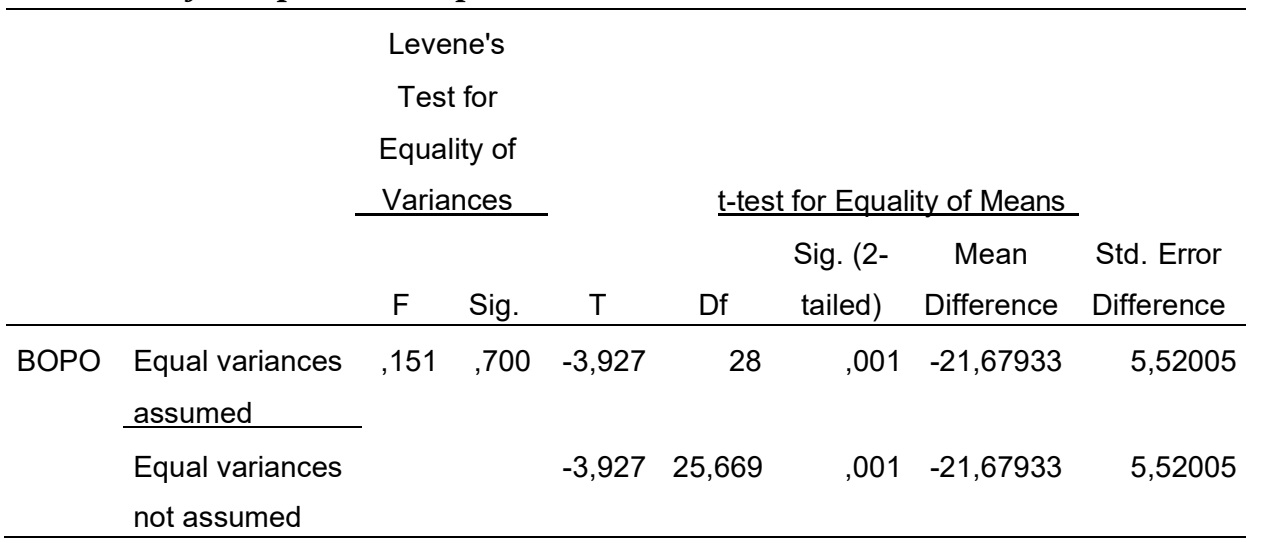

Sumber: Hasil ouput SPSS versi 25, 2020

F hitung untuk aspek Earnings atau rasio

CAR adalah pada Levene's Test sebesar 2,637 dengan probabilitas sebesar 0,116 karena $>0,05$ maka dapat disimpulkan bahwa memiliki variance yang sama. Dengan demikian analisis uji beda t-test menggunakan asumsi equal variances assumed. Jika dilihat dari T-Test pada equal variances assumed sebesar 1,391 dengan probabilitas signifikansi 0,175 (2-tailed). Nilai t-

tabel dengan taraf nyata $(\alpha)=5 \%$ dan $\mathrm{df}(\mathrm{n}-2)=$ $30-2=28$, adalah sebesar 1,701. Hal ini berarti $\mathrm{t}$ hitung $1,391<\mathrm{t}$ tabel 1,701, atau nilai signifikan $t$ hitung $0,175>0,05$ maka Ho diterima dan $\mathrm{Ha}$ ditolak. Artinya dari aspek Capital yaitu rasio (CAR) Current Assets Ratio tidak ada perbedaan tingkat kesehatan bank umum konvensional dan bank umum syariah.

Tabel 11. Hasil uji independent sample T-tes CAR

\begin{tabular}{|c|c|c|c|c|c|c|c|}
\hline & \multicolumn{2}{|c|}{$\begin{array}{c}\text { Levene's Test } \\
\text { for Equality of } \\
\text { Variances }\end{array}$} & \multicolumn{4}{|c|}{ t-test for Equality of Means } & \multirow[b]{2}{*}{$\begin{array}{l}\text { Std. Error } \\
\text { Difference }\end{array}$} \\
\hline & $\mathrm{F}$ & Sig. & $\mathrm{t}$ & df & $\begin{array}{l}\text { Sig. (2- } \\
\text { tailed) }\end{array}$ & $\begin{array}{c}\text { Mean } \\
\text { Difference }\end{array}$ & \\
\hline $\begin{array}{l}\text { Equal variances } \\
\text { assumed }\end{array}$ & 2,637 & ,116 & 1,391 & 28 & ,175 & 1,77600 & 1,27657 \\
\hline $\begin{array}{l}\text { Equal variances } \\
\text { not assumed }\end{array}$ & & & 1,391 & 23,177 & ,177 & 1,77600 & 1,27657 \\
\hline
\end{tabular}

Sumber: Hasil ouput SPSS versi 25, 2020

\section{Kesimpulan}

Berdasarkan hasil penelitian perbedaan yang telah dilakukan berdasarkan teori maka diambil kesimpulan dari penelitian ini adalah bahwa berdasarkan Tingkat Kesehatan Bank dengan metode RGEC, Bank Umum Konvensional masuk kategori sangat sehat dengan peringkat komposit 1 (PK-1), sedangkan Bank Umum Syariah masuk kategori kurang sehat dengan peringkat komposit 4 (PK-4) hal ini menunjukkan bahwa kinerja Bank Umum
Konvensional lebih baik dari pada Syariah. Berdasarkan hasil uji statistik Independent sample T-test menunjukan bahwa berdasarkan rasio LDR, GCG, dan CAR tidak ada perbedaan Tingkat Kesehatan Bank Umum Konvensional dan Bank Umum Syariah yang terdaftar di Bursa Efek Indonesia periode 20142018, sedangkan rasio NPL, ROA, ROE, NIM dan BOPO ada perbedaan kinerja keuangan Bank Umum Konvensional dan Bank Umum 
Syariah yang terdaftar di Bursa Efek Indonesia periode 2014-2018.

\section{Ucapan Terima Kasih}

Ucapan terimakasih ditujukan kepada Dr. Abid Djazuli, S.E, M.M Rektor Universitas Muhammadiyah Palembang (UMP), Drs. Fauzi Ridwan, S.E, M.M, Dekan FEB UmPalembang, Mafhtuhah Nurahmi, S.E, M.Si Ketua Jurusan Manajemen FEB UMPalembang serta Dosen Fakultas Ekonomi dan Bisnis UM-Palembang.

\section{Daftar Pustaka}

Alita, N. P. 2018. Analisis Perbandingan Kinerja Keuangan Perbankan Syariah dengan Perbankan Konvensional di Bursa Efek Indonesia.

Ariyanto, G. A. 2016. Analisis Perbandingan Kinerja Keuangan Bank Konvensional dan Bank Syariah periode 2010-2014. EJurnal Akuntansi Universitas Udayana Jurnal Kajian Ekonomi Islam Volume 3.. Betri. (2018).

Brigham, E. F. (2010). Akuntansi Perbankan. Palembang: Citrabooks.

Fahmi, i. 2012. Dasar-dasar Manajemen Keuangan Edisi 11. Jakarta: Salemba Empat.

Fitria, D. 2016. Analisis Laporan Keuangan. Bandung: Alfabeta.

Hery. 2018. Analisis Perbandingan Kinerja Keuangan Berdasarkan Risk Profile, Good Corporate Governance, Earnings and Capital (RGEC) Pada Bank Umum Konvensional dan Bank Umum Syariah Periode 2011-2014..

Iqbal, H. 2012. Analisis Laporan Keuangan. Jakarta: PT Grasindo.

Jumingan. 2009. Pokok-Pokok Materi Statistik 2 (statistik Inferensif). Jakarta: Bumi Aksara.

Kasmir. 2014. Analisis Laporan Keuangan. Jakarta: PT Bumi Aksara.

Kasmir. 2015. Dasar-Dasar Perbankan, Edisi Revisi. Jakarta: PT.Raja Grafindo Persada.

Norrahmiati. 2017. Analisis Laporan Keuangan. Jakarta: Rajawali Pers. Masterplan Arsitektur Keuangan Syariah. Jakarta: BAPPENAS.

Peraturan Bank Indonesia No.6/10/PBI Tahun 2004 Tentang Sistem Penilaian Tingkat Kesehatan Tentang Perbankan.
Bank Umum. Analisis Komperatif Kinerja Keuangan Berdasarkan Metode RGEC Pada Perusahaan Perbankan yang Terdaftar Di Bursa Efek Indonesia. Jurnal Scientific Volume 1.

Peraturan Bank Indonesia No.6/23/PBI Tahun 2004 Tentang Sistem Penilaian Tingkat Kesehatan Bank Umum. Peraturan Bank Indonesia No.9/12/PBI Tahun 2004 Tentang Pelaksanaan Good Corporate Governance Peraturan Bank Indonesia No.13/1/DPNP Tahun 2007 Tentang Penilaian Tingkat Kesehatan Bank Umum.

Peraturan Bank Indonesia No.13/1/DPNP Tahun 2011 Tentang Penilaian Tingkat Kesehatan Bank Umum. Peraturan Bank Indonesia No.13/24/DPNP Tahun 2011 Tentang Penilaian Tingkat Kesehatan Bank Umum.

Refmasari Veranda Aga dan Ngadirin Setiawan. 2014. Penilaian Tingkat Kesehatan Bank Umum Menggunakan Metode RGEC Dengan Cakupan Risk Profile, Earnings dan Capital Pada Bank Pembangunan Daerah Provinsi Istimewa Yogyakarta Tahun 2012.

Rudianto. 2013. Commercial Bank Management: Manajemen Perbankan dari Teori ke Praktik. Jakarta: Raja Grafindo Persada.

Sasa Elida Sovia, M. d. 2016. Akuntansi Pengantar. Jakarta: Erlangga. Analisis Perbandingan Kinerja Keuangan Bank Konvensional dan Bank Syariah Berdasarkan Rasio Keuangan Bank (Studi Pada Bank Konvensional yang Terdaftar di BEI yang Memiliki Bank Syariah Periode 2012- 2014). Jurnal Administrasi Bisnis Volume 37. Sistem Perbankan Indonesia, 2018.

Otoritas Jasa Keuangan. Sugiono. 2017.

Sutrisno. 2012. Metode Penelitian Kuantitatif, Kualitatif, dan R\&D. Alfabeta

Ekonisia. Taswan. 2010. Manajemen Keuangan. Yogyakarta.

Taswan. 2012. Akuntansi Perbankan: Transaksi Dalam Valuta Rupiah. Yogyakarta: UPP STIN YKPN.

Umam, K. 2017. Perbankan Syariah: Dasar-dasar dan Dinamika Perkembangannya di Indonesia. Jakarta: PT. Rajagrafindo Persada. UndangUndang No.10 Tahun 1998 